\title{
Effects of different low temperature storage conditions on the physico-chemical properties of Mastura (J37) jackfruit bulbs
}

Amiruddin Mat Joharia, Nur Aliaa Abd Rahmana,*, Azhari Samsu Baharuddina, Roseliza Kadir Bashaa, Mohd Afandi P. Mohammeda, Dzieda Muhamad Parida, Siti Zubaidah Abdul Razaka, Minato Wakisakab

${ }^{a}$ Department of Process and Food Engineering, Faculty of Engineering, Universiti Putra Malaysia, 43400 UPM Serdang, Selangor, Malaysia

${ }^{b}$ Graduate School of Life Science and Systems Engineering, Kyushu Institute of Technology, 2-4 Hibikino, Wakamatsu-ku, Kitakyushu, 808-0196, Japan

\section{ARTICLE HISTORY Abstract}

Received: 21 March 2020

Received in revised form: 28 March

2020

Accepted: 30 March 2020

Available Online: 2 April 2020

Keywords
Jackfruit
Low temperature storage
Vacuum packaging
Minimally process fruit
Food security

Mastura (J37) jackfruit planted in Pahang (Malaysia) is less preferred by the consumers and has caused backlog in the plantation as reported by Pahang State Farmers Association (PASFA). In this study, the proposed solution given was to use vacuum packaging to pack the bulbs and store them at $8-10^{\circ} \mathrm{C}$ (refrigerator) and $-18^{\circ} \mathrm{C}$ (deep-freezer). After 3 weeks of storage, deep-frozen vacuum-packed bulbs had lower ripening index (265) and microbial count $\left(6 \times 10^{2} \mathrm{cfu} / \mathrm{ml}\right)$ when compared to refrigerated vacuum-packed bulbs which had higher ripening index $(629)$ and higher microbial count $\left(52 \times 10^{2} \mathrm{cfu} / \mathrm{ml}\right)$. The lightness, $L^{*}$ value of vacuum-packed jackfruit bulb samples under deep-freeze storage was higher compared to the ones under refrigeration storage. The output obtained from this work provides preliminary data which are useful for Mastura (J37) jackfruit further downstream processing. These data are helpful as they contribute towards the understanding of further processing of this particular jackfruit variety into end products, in order to solve the issue faced by PASFA.

\section{Introduction}

Jackfruit in its mature stage comprises of parts known as the outer rind, inner rind, rags, bulbs/arils, seed and core. Jackfruit is a climacteric fruit with a short shelf life. It turns brown and deteriorates rapidly after ripening. The ripening process depends on the maturity of fruit, ambient temperature of surrounding and the relative humidity of the environment. Harvested ripe jackfruits may be stored for four to five days at ambient temperature and relative humidity of $65-75 \%$, while low temperature of $13.3{ }^{\circ} \mathrm{C}$ with relative humidity of $85-90 \%$ increase its shelf life up to 45 days (Thompson, 2014). The fruit has 94 calories per $100 \mathrm{~g}$ fresh weight with complete source of vitamin A and C. The pulp has carbohydrates $(23.4 \%)$, protein $(0.6 \%)$, fat $(0.6 \%)$, minerals $(0.9 \%)$, fibre $(1.8 \%)$ and ash $(0.5 \%)$. The seed contains $0.4 \%$ fat, $1.5 \%$ fibre and $1.5 \%$ of ash (Haq, 2006; Swami et al., 2012). Crane et al. (2005) reported that $100 \mathrm{~g}$ of fresh jackfruit has $73 \%$ moisture, $24 \mathrm{~g}$ carbohydrates, $1.5 \mathrm{~g}$ protein, $0.3 \mathrm{~g}$ fat, $1.6 \mathrm{~g}$ fibre and $94 \mathrm{kcal}$ energy. The average total soluble solid content of 40 genotypes of jackfruit was 22.56 with observed ${ }^{\circ}$ Brix ranging from 13.72 to 32.40 (Aseef et al., 2017).

In Malaysia, the rise of different varieties of jackfruit recorded in 2011 such as Mantin (J32) and Tekam yellow (J33) created a competition for Mastura (J37) in the jackfruit market (Ismail \& Kaur, 2013). Pahang State Farmers Association (PASFA) reported a surplus of Mastura jackfruit when the demand of Tekam yellow jackfruit peaked during its season. This was explained by Ismail \& Kaur (2013), in which Mastura jackfruit was less preferred by consumers due to its low sweetness and high juiciness properties. The low demand of Mastura jackfruit caused backlog in the plantation which eventually lead to waste. A plan to turn the low demand Mastura jackfruit into useful products to enable further processing of the flesh was proposed to PASFA to solve the issue. Furthermore, PASFA reported that their current use of plastic and styrofoam packaging for storing jackfruit bulbs under refrigeration only enabled them to keep the bulbs for up to 7-10 days of storage. After the period, the depletion of the shelf life of jackfruit bulbs occurred.

Minimally processed jackfruit bulbs are highly perishable due to its high respiratory behaviour, nonetheless, studies of vacuum packaging techniques have been successful in increasing the shelf life and quality of fruit (Saxena et al., 2008; Farheen, 2013). Vacuum packaging (VP) removes air during the final sealing of package. This method of modification of atmosphere is used to inhibit aerobic bacteria, oxidative reactions, and spoilage agents. The application of VP inhibits the progressive stages of food deterioration. VP refers to removal of air from packaging prior to final sealing of package. This is considered as a 'modified atmosphere' technique which normal ambient air is expelled from the container. Farheen et al. (2016) suggested the use of VP on minimally processed jackfruit as it enhances the shelf-life and restricts the total soluble solid, titratable acidity and microbial load when stored in low temperature. Different types of fruits have been packed using the VP method. Nair and Tung (1988) used VP on Pisang Mas bananas which proved to extend the shelf life to 4-6 weeks when stored at $17^{\circ} \mathrm{C}$. The bananas were kept in in PE bags and vacuum packed not exceeding $300 \mathrm{~mm} \mathrm{Hg}(40 \mathrm{kPa})$. Geetha \& Thirumaran (2010) had also studied the effect of VP on the shelf life of papaya. They had found that fruits with this method and stored at ambient and refrigeration temperatures had increase in shelf life to one week and four weeks, respectively. Moisture, acidity and vitamin contents of papaya decreased during storage whereas total soluble solids increased.

A method proposed to PASFA was to use vacuum packaging technique to further increase the shelf life of jackfruit bulbs. Mastura jackfruit must be properly processed and packed in order to increase its storage life while retaining the qualities of its bulbs. This research aimed to investigate the effects of 
refrigerated and deep-frozen vacuum-packed storage on the physico-chemical properties of Mastura (J37) jackfruit bulbs.

\section{Materials and methods}

\subsection{Materials}

Mastura (J37) jackfruit variety were purchased from the Pahang State Farmers Association (PASFA) factory in Pahang, Malaysia. The fruits obtained were determined matured and ripened through observation of yellowish dark patches on the outer rind, a hollow sound produced when tapped and the less hardness of the skin when giving slight pressure. The fruits were placed in a refrigeration storage at $8-10^{\circ} \mathrm{C}$ to prevent over ripening. Jackfruits were then cleaned using water and brushed to remove external dirt. The fruits were cut using a sharp stainless-steel knife smeared with cooking oil. Fruit bulbs were separated from its whole fruit and deseeded.

\subsection{Packaging and storage of raw jackfruit bulbs}

The minimally processed jackfruit bulbs were packed in polyethylene (PE)/polypropylene (PP) packaging plastics with total thickness of 160 microns as shown in Figure 1. Approximately $300 \mathrm{~g}$ of jackfruit bulbs in each batch were vacuum packed using a vacuum sealer (Model DZ-400, Sunwins, Malaysia) and stored in refrigerator (Model BS2DUC/Z, Berjaya, Malaysia) at $0-5^{\circ} \mathrm{C}$ and deep-freezer (Model EF-5500, Elba, Italy) at $-18^{\circ} \mathrm{C}$. Preliminary studies done by Latifah et al. (2000) and Farheen et al. (2016) indicated that jackfruit bulbs without pretreatment and stored in refrigeration storage had a shorter shelf life of only 3 weeks while jackfruit bulbs stored in freezer had a shelf life up to 6 weeks. In this study the jackfruit bulbs stored in refrigeration storage also became damaged after 3 weeks of storage. The damage was observed from the visible moulds. The detail of the experiment is presented in Table 1.

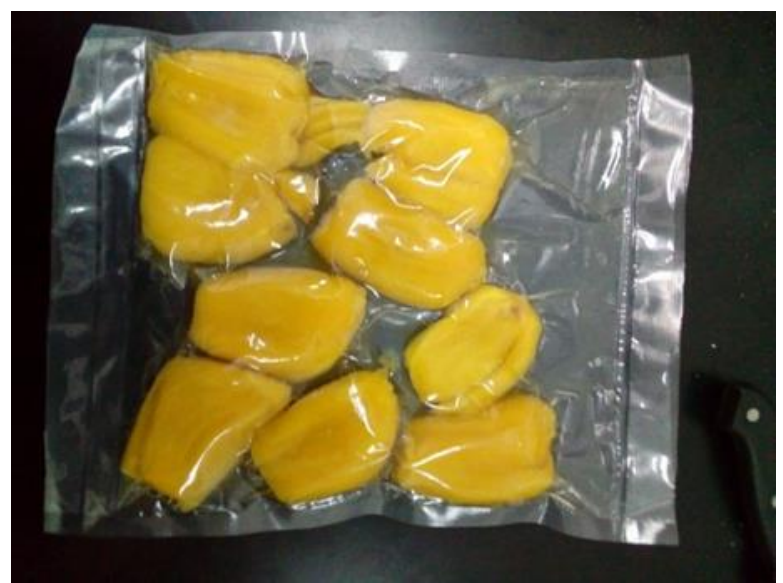

Figure 1. Vacuum packaging of jackfruit bulbs in a PE/PP plastic

\subsection{Colour of jackfruit bulb}

Colour is the first quality attribute of food evaluated by consumers making it an important component of food quality relevant to market acceptance (Wu \& Sun, 2013). The Hunterlab colour scale was used to determine the colour of the samples. The colour test was performed using a colour spectrophotometer (HunterLab Ultrascan Pro, Reston, VA). Three reading values were taken for each sample. Colour values $\left(L^{*}, a^{*}\right.$, and $\left.b^{*}\right)$ of vacuum-packed jackfruit bulbs stored at different storage conditions were analysed. The $L^{*}$ scale represents light vs. dark where a low number $(0-50)$ indicates dark and a high number (51-100) indicates light. The $a^{*}$ scale represents red vs. green where a positive number indicates red and a negative number indicates green. The $b^{*}$ scale represents yellow vs. blue in which a positive number indicates yellow and a negative number indicates blue.

\subsection{Puncture test: bio-yield point of jackfruit bulb}

Bio-yield is determined to be the point of loading that results in a permanent set of physical damage to fresh fruit. Bioyield point is an indication of initial cell rupture in the cellular structure of the material. It is considered as the force required causing permanent deformation. It is also the point on the force deformation curve at which an increase in deformation occurs with a decrease or no change of the applied force (Lubomír \& Viera, 2015). The bio-yield point was determined by the modified method of Saxena et al. (2012). Texture of vacuumpacked jackfruit bulb was measured using a texture analyser (Model TA. XT Plus, Stable Micro Systems ${ }^{\mathrm{TM}}$, England). The fruit bulb slices were punctured using a cylindrical probe $(\mathrm{d}: 5 \mathrm{~mm})$ at a speed of $2 \mathrm{~mm} . \mathrm{s}^{-1}$. Values were recorded in triplicate. Bioyield point of the sample was determined based on the force recorded on the chart in Newton $(\mathrm{N})$.

\subsection{Total soluble solid (TSS) of jackfruit bulb}

TSS is regarded as an important quality parameter in fruit. It is highly correlated with sugar content and measured as ${ }^{\circ} \mathrm{Brix}$. The content includes carbohydrates, organic acids, proteins, fats and minerals of fruits. Samples were crushed and made into juice. TSS was measured using a digital refractometer (AR2008, A. KRÜSS Optronic, Germany) by standard method.

\subsection{Titratable acidity (TA) of jackfruit bulb}

Titratable acidity represents the amount of acid in food material. The titratable acidity of jackfruit bulb samples was determined by the visual titration method (Ranganna, 1986). A $10 \mathrm{~g}$ sample of pulp was taken in a $100 \mathrm{ml}$ beaker and a little quantity of distilled water was added to it. The mixture was then gently boiled in a water bath for 1 hour. Water was occasionally added to replace evaporated water. After cooling, the mixture was transferred to a $100 \mathrm{ml}$ volumetric flask. The mixture was then filtered through Whatman No. 4 filter paper and the filtrate was used for analysis. $10 \mathrm{ml}$ of filtrate was poured in a conical flask and titrated against $0.1 \mathrm{~N} \mathrm{NaOH}$ solution in a burette using 1 or 2 drops of phenolphthalein indicator. Formation of pink colour was observed at the end point of titration. The titration was repeated until consistent values were obtained. Titratable acidity was calculated based on Equation 1 as follows:

$$
\mathrm{TA}(\%)=\frac{V_{\text {titrate }} \times \mathrm{N} \text { of } \mathrm{NaOH} \times \text { citric acid }}{V_{\text {sample }}} \times 100
$$

where $V_{\text {titrate }}$ is the volume of base $(\mathrm{ml}), \mathrm{N}$ of $\mathrm{NaOH}$ is $0.1 \mathrm{~N}$, milliequivalent factor of citric acid is 0.0064 and $V_{\text {sample }}$ is the volume of sample.

\subsection{Ripening index (RI) of jackfruit bulb}

Evaluation of ripening behavior of fruits include changes in biochemical, physiological composition, color, textural and rheological properties (Nambi et al., 2017). Ripening index can be calculated as the ratio of total soluble solid (TSS) to titratable acidity (TA) based on the study done by Majidi et al. (2011). The ratio indicates the maturity of fruit and the balance between total soluble solid and acidity of the jackfruit bulb. RI was calculated using Equation 2: 
Table 1. Vacuum packaging of jackfruit bulbs

\begin{tabular}{lllll}
\hline No. & Storage type & Storage temperature $\left({ }^{\circ} \mathrm{C}\right)$ & Storage period (weeks) & Packaging plastic \\
\hline 1. & Refrigerator & $0-5$ & 3 & Polyethylene/Polypropylene \\
2. & Deep-freezer & -18 & 6 & Polyethylene/Polypropylene \\
\hline
\end{tabular}

$$
\mathrm{RI}=\frac{\text { Total soluble solid }(\mathrm{TSS})}{\text { Titratable acidity (TA) }}
$$

\subsection{Microbial count in jackfruit bulbs}

The jackfruit bulbs were subjected to microbial analysis by employing Dilution Plate Count method (Padmanabhan \& Heinz, 1985). For enumeration of bacterial counts, a $10 \mathrm{~g}$ sample of jackfruit bulbs was weighed aseptically and blended with $100 \mathrm{ml}$ sterile water and subsequent dilutions were prepared up to $10^{-}$ ${ }^{4}$ by transferring $1 \mathrm{ml}$ aliquot from $10^{-1}$ to $9 \mathrm{ml}$ water blank. The filtrates, serially diluted to $10^{-1}, 10^{-2}, 10^{-3}$, and $10^{-4}$, were spread on a suitable medium in duplicate. The culture media used were Nutrient agar and Plate Count Agar (PCA) for coliforms and total counts respectively. Required dilution of $0.1 \mathrm{ml}$ was transferred to sterilized petri plates. The plates were shaken in anticlockwise direction to attain uniform distribution of dilution to the culture media. The plates were then allowed to solidify the media and incubated for $2-3$ days at $30^{\circ} \mathrm{C}$. The plates were then observed for coliforms and total counts. The total coloured colonies were counted and results expressed as bacteria per ml were determined using the Equation 3:

Total plate count $=\frac{\text { Number of CFU } \times \text { Dilution factor }}{\text { Volume plated }}$

where the total plate count is expressed in bacteria per ml.

\subsection{Statistical analysis}

The analysis of variance (ANOVA) was carried out to analyse the results. The comparisons of different storage weeks were performed with Tukey's test $(P \leq 0.05)$. Data analysis was performed using the software SPSS statistics version 25.0 (SPSS In., Chicago, IL).

\section{Results and discussions}

\subsection{Colour of jackfruit bulb}

The changes in colour of jackfruit bulbs are reported in Table 2 for refrigeration and deep-freeze storages. The initial $L^{*}$, $a^{*}$, and $b^{*}$ values at week 0 for the bulb samples were 68.52 , 10.42 and 57.48, respectively. Samples under refrigeration storage had a reduction of $L^{*}$ value to $54.62, a^{*}$ value to 9.07 and $b^{*}$ value to 47.39 after 3 weeks of storage. Samples under deepfreeze storage had an $L^{*}$ value of 55.72, $a^{*}$ value of 7.37 and $b^{*}$ value of 38.88 after 3 weeks of storage.

After 6 weeks of storage, the samples under deep-freeze storage had slightly lower $L^{*}$ value of $65.23, a^{*}$ value of 4.89 and $b^{*}$ value of 43.76 in comparison to the colour characteristics of jackfruit bulbs at week $0 . L^{*}$ values reduced for both storage conditions due to darkening of bulbs. This is due to skin browning of fruit surface as oxidation of polyphenols and formation of dark coloured pigments occur (Cia et al., 2006). However, the $L^{*}$ value of vacuum-packed jackfruit bulb samples under deep-freeze storage was still higher compared to the bulbs under refrigeration storage. Aside from the effect of vacuum packaging that reduces oxygen level coming into contact with the product, low temperature storage also results in minimum oxygen concentration inside the package as reported by Farheen (2013). This causes slow respiration rates of bulbs, enzymatic browning and oxidative deterioration processes. The slight inconsistencies in the values of $L^{*}, a^{*}$ and $b^{*}$ were due to the characteristics of Mastura jackfruit itself in which it has high water content as reported by Ismail and Kaur (2013).

\subsection{Puncture test: bio-yield point of jackfruit bulbs}

The bio-yield point indicates the cell rupture in the structure of the sample. The results of bio-yield point showed that storage time had an effect on the cell rupture of Mastura jackfruit bulb. Table 3 shows results for the bulbs stored from 0 to 3 weeks under refrigeration storage and 0 to 6 weeks under deep-freeze storage. It was found that the bio-yield point of jackfruit bulbs under refrigeration storage decreased from 4.55 to $2.58 \mathrm{~N}$ while the bulbs under deep-freeze storage had a significant decreasing trend from 4.55 to $1.05 \mathrm{~N}$ after 3 weeks. The results of puncture test depend on the turgor pressure of the fruit, the firmness of flesh and the mechanical strength of the skin (Holt, 1970). The decreasing trend of bio-yield point was due to decreasing turgor pressure and wall integrity of the jackfruit bulbs. Post-harvest storage of fruit is followed by the loss of cell-wall integrity from the breakdown of pectin substance that would lead to an increase in soluble pectin and decrease the firmness of fruit (Mirdehghan et al., 2007).

However, bulbs kept in deep-freeze storage for 4 to 6 weeks showed bio-yield point results of 2.88 to $2.61 \mathrm{~N}$. There was no significant difference between the readings for week 4-6 compared with week 2 of vacuum-packed sample in deep-freeze storage. This might be due to the water loss from the jackfruit bulbs which caused cell rupture to occur at similar forces during the puncture tests. According to James \& James (2014), chilling injury causes an increase in loss of cell-wall integrity. This mechanism of damage is caused by ice crystals and causes a loss of water-holding capacity due to tissue damage.

\subsection{Total soluble solid (TSS) of jackfruit bulb}

Data in Table 3 indicated an increase of TSS in all samples during both storage conditions. This is related to the conversion of organic acid into starch and sugar through the process of gluconeogenesis (Saxena et al., 2008) as the fruits undergo the process of ripening. However, vacuum packed samples under refrigeration storage had higher TSS of $17.3^{\circ}$ Brix compared to vacuum packed samples under deep-freeze storage which was $16.4^{\circ} \mathrm{Brix}$ in week 3. This is because of an increase of rate of metabolism with higher temperature, hence faster consumption of compounds such as the organic acids that serve as metabolic substrates (Famiani et al., 2015). After week 6, the TSS value of the sample kept under deep-freeze storage was $19.3^{\circ} \mathrm{Brix}$. This indicated that long period of storage period would result in higher soluble solids in fruit as more organic acid was turned into starch and sugar.

\subsection{Titratable acidity (TA) of jackfruit bulb}

Titratable acidity (TA) represents the quantity of acid in sample. The data of titratable acidity of vacuum-packed jackfruit bulbs during different storage conditions are also presented in Table 3. Initially, vacuum-packed samples under both storage condition had a TA of $0.1216 \%$ in week 0 . Samples under refrigeration storage had a TA of $0.0512 \%$ in week 1 and 
Table 2. Influence of vacuum packaging of minimally processed jackfruit bulbs on colour under different storage conditions

\begin{tabular}{|c|c|c|c|c|c|c|}
\hline \multirow{3}{*}{$\begin{array}{l}\text { Storage period } \\
\text { (week) }\end{array}$} & \multicolumn{6}{|l|}{ Colour } \\
\hline & \multicolumn{3}{|l|}{$\begin{array}{l}\text { Ref. storage } \\
\left(3-5^{\circ} \mathrm{C}\right)\end{array}$} & \multicolumn{3}{|c|}{$\begin{array}{l}\text { Deep-freeze storage } \\
\left(-18^{\circ} \mathrm{C}\right)\end{array}$} \\
\hline & $L^{*}$ & $a^{*}$ & $b^{*}$ & $L^{*}$ & $a^{*}$ & $b^{*}$ \\
\hline 0 & $68.52 \pm 0.78^{b}$ & $10.42 \pm 0.92^{b}$ & $57.48 \pm 2.49 c$ & $68.52 \pm 0.78^{\mathrm{e}}$ & $10.42 \pm 0.92^{\mathrm{d}}$ & $57.48 \pm 2.49 c$ \\
\hline 1 & $68.02 \pm 0.78^{b}$ & $9.44 \pm 0.79 \mathrm{ab}$ & $53.62 \pm 2.32^{c}$ & $56.69 \pm 0.93^{\mathrm{ab}}$ & $8.59 \pm 0.58^{\mathrm{cd}}$ & $44.69 \pm 1.24^{b}$ \\
\hline 2 & $58.39 \pm 0.10^{c}$ & $7.74 \pm 1.15^{\mathrm{a}}$ & $44.24 \pm 2.53^{b}$ & $60.15 \pm 1.48^{c}$ & $4.95 \pm 1.40^{\mathrm{a}}$ & $45.06 \pm 1.63^{b}$ \\
\hline 3 & $54.62 \pm 0.19^{a}$ & $9.07 \pm 0.03^{\mathrm{ab}}$ & $47.39 \pm 0.14^{b}$ & $55.72 \pm 0.75^{\mathrm{a}}$ & $7.37 \pm 0.09 \mathrm{bc}$ & $38.88 \pm 0.41^{\mathrm{a}}$ \\
\hline 4 & $\mathrm{~N} / \mathrm{A}$ & $\mathrm{N} / \mathrm{A}$ & N/A & $55.98 \pm 0.20^{\mathrm{bc}}$ & $9.72 \pm 0.12^{\mathrm{d}}$ & $44.74 \pm 0.43^{b}$ \\
\hline 5 & $\mathrm{~N} / \mathrm{A}$ & $\mathrm{N} / \mathrm{A}$ & $\mathrm{N} / \mathrm{A}$ & $65.53 \pm 0.08^{d}$ & $6.69 \pm 0.06^{\mathrm{ab}}$ & $42.88 \pm 0.32^{b}$ \\
\hline 6 & $\mathrm{~N} / \mathrm{A}$ & $\mathrm{N} / \mathrm{A}$ & $\mathrm{N} / \mathrm{A}$ & $65.23 \pm 1.76^{\mathrm{de}}$ & $4.89 \pm 0.02^{\mathrm{a}}$ & $43.76 \pm 0.18^{b}$ \\
\hline
\end{tabular}

Ref. - Refrigerator; $L^{*}$ - Lightness coordinate; $a^{*}$ - Green [-] to red [+] colour space coordinate; $b^{*}$-Blue [-] to yellow [+] colour space coordinate; a-eMeans with different letters in the same column are significantly different $(P<0.05)$; N/A is not available due to damage of bulb from high microbial count

Table 3. Influence of vacuum packaging of minimally processed jackfruit bulbs on bio-yield point, total soluble solid, titratable acidity and ripening index under different storage conditions

\begin{tabular}{|c|c|c|c|c|c|c|c|c|}
\hline & \multicolumn{2}{|c|}{ Bio-yield point $(\mathrm{N})$} & \multicolumn{2}{|c|}{ Total soluble solid ( $\left.{ }^{\circ} \mathrm{Brix}\right)$} & \multicolumn{2}{|c|}{ Titratable acidity (\%) } & \multicolumn{2}{|c|}{ Ripening index (RI) } \\
\hline $\begin{array}{l}\text { Storage } \\
\text { period } \\
\text { (week) }\end{array}$ & $\begin{array}{l}\text { Ref. storage } \\
\left(3-5^{\circ} \mathrm{C}\right)\end{array}$ & $\begin{array}{l}\text { Deep- } \\
\text { freeze } \\
\text { storage } \\
\left(-18^{\circ} \mathrm{C}\right)\end{array}$ & $\begin{array}{l}\text { Ref. storage } \\
\left(3-5^{\circ} \mathrm{C}\right)\end{array}$ & $\begin{array}{l}\text { Deep- } \\
\text { freeze } \\
\text { storage } \\
\left(-18^{\circ} \mathrm{C}\right)\end{array}$ & $\begin{array}{l}\text { Ref. storage } \\
\left(3-5^{\circ} \mathrm{C}\right)\end{array}$ & $\begin{array}{l}\text { Deep-freeze } \\
\text { storage } \\
\left(-18^{\circ} \mathrm{C}\right)\end{array}$ & $\begin{array}{l}\text { Ref. } \\
\text { storage } \\
\left(3-5^{\circ} \mathrm{C}\right)\end{array}$ & $\begin{array}{l}\text { Deep- } \\
\text { freeze } \\
\text { storage } \\
\left(-18^{\circ} \mathrm{C}\right)\end{array}$ \\
\hline 0 & $4.55 \pm 0.03^{c}$ & $4.55 \pm 0.03^{c}$ & $15.2 \pm 0.1^{\mathrm{a}}$ & $15.2 \pm 0.1^{\mathrm{a}}$ & $0.1216 \pm 0.0128^{c}$ & $0.1216 \pm 0.0128^{c}$ & 125.0 & 125.0 \\
\hline 1 & $4.16 \pm 0.25^{\mathrm{d}}$ & $3.80 \pm 0.11^{\mathrm{c}}$ & $16.3 \pm 0.3^{\mathrm{ab}}$ & $15.7 \pm 0.3^{\mathrm{ab}}$ & $0.0512 \pm 0.064^{\mathrm{b}}$ & $0.1003 \pm 0.0098^{\mathrm{c}}$ & 318.4 & 156.5 \\
\hline 2 & $3.25 \pm 0.13^{\mathrm{b}}$ & $2.65 \pm 0.01^{b}$ & $16.4 \pm 1.1^{\mathrm{ab}}$ & $16.1 \pm 0.2 \mathrm{bc}$ & $0.0299 \pm 0.098^{\mathrm{ab}}$ & $0.0619 \pm 0.0098^{\mathrm{b}}$ & 592.1 & 260.1 \\
\hline 3 & $2.58 \pm 0.07 \mathrm{a}$ & $1.05 \pm 0.06^{\mathrm{a}}$ & $17.3 \pm 0.3^{\mathrm{b}}$ & $16.4 \pm 0.3^{\mathrm{cd}}$ & $0.0277 \pm 0.037 \mathrm{a}$ & $0.0619 \pm 0.0037 \mathrm{~b}$ & 624.5 & 265.0 \\
\hline 4 & $\mathrm{~N} / \mathrm{A}$ & $2.88 \pm 0.70^{\mathrm{b}}$ & $\mathrm{N} / \mathrm{A}$ & $16.7 \pm 0.2^{\mathrm{cd}}$ & $\mathrm{N} / \mathrm{A}$ & $0.0533 \pm 0.0037 \mathrm{ab}$ & $\mathrm{N} / \mathrm{A}$ & 313.3 \\
\hline 5 & $\mathrm{~N} / \mathrm{A}$ & $2.36 \pm 0.19 \mathrm{~b}$ & $\mathrm{~N} / \mathrm{A}$ & $17.0 \pm 0.2^{\mathrm{d}}$ & $\mathrm{N} / \mathrm{A}$ & $0.0512 \pm 0.0111^{\mathrm{ab}}$ & $\mathrm{N} / \mathrm{A}$ & 332.0 \\
\hline 6 & $\mathrm{~N} / \mathrm{A}$ & $2.61 \pm 0.05^{b}$ & $\mathrm{~N} / \mathrm{A}$ & $19.3 \pm 0.4 \mathrm{e}$ & $\mathrm{N} / \mathrm{A}$ & $0.0363 \pm 0.0037 a$ & $\mathrm{~N} / \mathrm{A}$ & 531.7 \\
\hline
\end{tabular}

a-eMeans with different letters in the same column are significantly different $(P<0.05)$. N/A is not available due to damage of bulb from high microbial count

decreased significantly to $0.0277 \%$ in week 3 . Vacuum-packed samples under deep-freeze also depicted a significant decrease of TA of $0.1003 \%$ in week 1 to $0.0619 \%$ in week 3 .

However, the reduction of TA for samples under refrigeration storage were faster compared to the samples under deep-freeze storage. Results showed a decrease of titratable acidity of jackfruit samples under both refrigeration storage and deep-freeze storage. This characteristic regarding the reduction of titratable acidity after ripening was also reported in many fruits with organic acids such as citric and malic as reported Famiani et al. (2015). The reduction throughout the weeks suggested the conversion of these organic acids present in the samples into sugars through the process of gluconeogenesis. However, environmental factors include temperature would also influence the rate of metabolic processes in the fruit. Rate of respiration of fruits as temperature increases has also been shown in many studies in which organic acids may be transported into the mitochondria for respiration as reported by Sweetman et al. (2014). Hence resulting a faster rate and higher reduction titratable acidity for samples under refrigeration storage compared to the sample under deep-freeze storage. Deep-freeze storage reduces the reduction rate of the TA as the metabolism rate of the fruit decreases. Hence, slower consumption of organic acids which serves as metabolic substrates as reported by Famiani et al. (2015).

\subsection{Ripening index (RI) of jackfruit bulb}

Ripening index (RI) is the ratio of TSS to TA that indicates the maturity of fruit and balance between total soluble solid and titratable acidity as stated by Majidi et al. (2011). The ripening index (RI) for the samples are tabulated in Table 3. Vacuum packed samples under deep-freeze storage rose from an RI of 125.0 in week 0 to 265.0 in week 3. Vacuum-packed samples under deep-freeze storage proved to be more effective in restricting the ripeness index of approximately 2 -fold higher in week 3 . On the other hand, the vacuum-packed samples under refrigeration storage had risen from an RI of 125.0 in week 0 to 624.5 in week 3. Samples were observed to have restricted rise of around 5-fold in week 3.

Even though jackfruit samples were stored in deep-freeze storage up to week 6 , the ripeness index was only around 4.2fold higher than its initial value. A slower increase in RI for samples under deep-freeze storage was due to its TSS and TA. Saxena et al. (2008) stated that ripening occurs when organic acid is converted into starch and glucose through the process of gluconeogenesis. However, low temperature condition in the deep-freeze storage restricted the rate of metabolism of the samples. This slowed down the process of conversion resulting in a lower RI as opposed to the RI value in vacuum-packed samples under refrigeration storage. Since RI is dependent on the TSS and TA of the jackfruit, it would be difficult to pinpoint a good range of RI for a specific jackfruit variety.

\subsection{Microbiological count in jackfruit bulbs}

The microbial analysis given by the microbial profile through the total plate counts (PCA) method are tabulated in Table 4. Combination of vacuum packaging and deep-freeze storage were found to be effective in delaying further microbial contamination of jackfruit bulb samples. The total counts observed in week 3 for vacuum packaging of jackfruit bulbs under refrigeration storage was significantly higher compared with the samples under deep-freeze storage in the same week. Microbial counts were still low in using deep-freeze storage despite samples being stored up to week 6. According to Abadias 
et al. (2008), the combination of low $\mathrm{pH}$ and low temperature during storage of minimally during storage of minimally processed food products tend to inhibit growth of microorganisms. The spoilage of fruits may also be related to the utilization of organic acids by specific microbes as reported by Farheen (2013). Microbial colony was observed during the early stages in both storage conditions yet, the counts are under the safe minimum threshold level. Guidelines stated that vacuumpacked products such as fruits and vegetables should have a satisfactory colony-forming unit of less than $10^{6}$ (Health Protection Agency, 2009).

Table 4. Influence of vacuum packaging of minimally processed jackfruit bulbs on microbial counts $(\mathrm{cfu} / \mathrm{ml})$ under different storage conditions

\begin{tabular}{lll}
\hline \multicolumn{2}{l}{ Microbial count $\left(10^{2} \mathrm{cfu} / \mathrm{ml}\right)$} \\
\hline $\begin{array}{l}\text { Storage period } \\
\text { (week) }\end{array}$ & $\begin{array}{l}\text { Ref. storage } \\
\left(3-5^{\circ} \mathrm{C}\right)\end{array}$ & $\begin{array}{l}\text { Deep-freeze storage } \\
\left(-18^{\circ} \mathrm{C}\right)\end{array}$ \\
\hline 0 & 0 & 0 \\
1 & 15 & 4 \\
2 & 32 & 5 \\
3 & 52 & 6 \\
4 & N/A & 14 \\
5 & N/A & 17 \\
6 & N/A & 39 \\
\hline
\end{tabular}

N/A is not available due to damage of bulb from high microbial count

As stated previously, the jackfruit bulbs stored in refrigeration storage also became damaged after 3 weeks of storage which can be observed from the visible moulds.

\section{Conclusion}

Both refrigeration and deep-freeze storages help preserve the quality of vacuum-packed jackfruit bulbs. Frozen vacuumpacked jackfruit bulb had slower reduction of colour $\left(L^{*}\right)$ and high increase in bio-yield point. It also has slower increasing rate of TSS, slower decreasing rate of TA and slower increment of ripeness. Frozen vacuum-packed samples also had lower microbial count compared to the refrigerated ones. Storage of vacuum-packed samples under subfreezing temperature ($18^{\circ} \mathrm{C}$ ) has improved the quality of the minimally processed Mastura jackfruit bulb. This work contributed in providing useful preliminary data towards further processing of Mastura (J37) jackfruit which is intended to solve the surplus issue faced by the plantation and factory.

\section{Author contributions}

Amiruddin Mat Johari: conceptualization, methodology, data curation, and writing of the original draft. Nur Aliaa Abd Rahman: supervision, project administration, reviewing, and editing of the final manuscript. Azhari Samsu Baharuddin: supervision and resources. Roseliza Kadir Basha: supervision and reviewing of manuscript. Mohd Afandi P. Mohammed: supervision and resources. Dzieda Muhamad Parid: reviewing of manuscript. Siti Zubaidah Abdul Razak: reviewing of manuscript. Minato Wakisaka: resources.

\section{Conflict of interests}

The authors declare that they have no known competing financial interests or personal relationships that could have appeared to influence the work reported in this paper.

\section{Acknowledgments}

The authors would like to thank Universiti Putra Malaysia (GP/IPS/9518100) for the funding and Pahang State Farmers Association (PASFA) for working closely with the team to make this study a success.

\section{References}

Abadias, M., Usall, J., Oliveira, M., Alegre, I., \& Vinas, I. (2008). Efficacy of neutral electrolyzed water (NEW) for reducing microbial contamination on minimally-processed vegetables. International Journal of Food Microbiology, 123, 151-158. https://doi.org/10.1016/j.ijfoodmicro.2007.12.008

Aseef, R.M., Manikandan, K., Kavino, M., Vijayakumar, R.M. \& Ganesan, N.M. (2017). Biochemical evaluation of local genotypes of jackfruit (artocarpus heterophyllus Lam.) in Pudukkottai district. Journal of Pharmacognosy and Phytochemistry, 6(5): 2533-2536. http://www.phytojournal.com/archives/2017/vol6issue5 /PartAK/6-5-439-773.pdf

Cia, P., Benato, E.A., Sigrist, J.M.M., Sarantopóulos, C., Oliveira, L.M. \& Padula, M. (2006). Modified atmosphere packaging for extending the storage life of 'fuyu' persimmon. Postharvest Biology and Technology, 42(3): 228-234. https://doi.org/10.1016/j.postharvbio.2006.06.016

Crane, J.H., Balerdi, C. \& Maguire, I. (2005). Jackfruit growing in the Florida home landscape. Fact Sheet HS-882. Florida Cooperative Extension Service, University of Florida, USA: 1-10.

Famiani, F., Battistelli, A., Moscatello, S., Cruz-Castillo, J.G. \& Walker, R.P. (2015). The organic acids that are accumulated in the flesh of fruits: Occurrence, metabolism and factors affecting their contents-a review. Revista Chapingo Serie $\begin{array}{lll}\text { Horticultura, } & 21(2): & \text { 97-128. }\end{array}$ http://dx.doi.org/10.5154/r.rchsh.2015.01.004

Farheen, T., Ranganna, B. \& Munishamanna, K.B. (2013). Vacuum packaging of minimally processed jackfruit (artocarpus heterophyllus l.) bulbs for long distance transportation. Mysore Journal of Agricultural Sciences, 48(3): 351-357.

Farheen, T., Ranganna, B. \& Munishamanna, K.B. (2016). Vacuum packaging of minimally processed un-ripe jackfruit (artocarpus heterophyllus l.) bulbs. Science \& Technology, 2(5): 35-39. http://discoveryjournals.org/sciencetech/Current_Issue/ 2016/A4.pdf

Geetha, P. \& Thirumaran, A.S. (2010). Increasing the shelf-life of papaya through vacuum packing. International Society for Horticultural Science (ISHS), Leuven, Belgium: pp: 527-532. https://doi.org/10.17660/ActaHortic.2010.851.80

Haq, N. (2006). Fruits for the future 10 - jackfruit (artocarpus heterophyllus) monograph. Southampton Centre for Underutilized Crops, University of Southampton, UK.

Holt, C.B. (1970). Measurement of tomato firmness with a universal testing machine. Journal of Texture Studies, 1(4): 491-501. 4603.1970.tb00747.x

Health Protection Agency (2009). Guidelines for assessing the microbiological safety of ready-to-eat foods. London: Health Protection Agency. https://assets.publishing.service.gov.uk/government/uplo ads/system/uploads/attachment_data/file/363146/Guide lines_for_assessing_the_microbiological_safety_of_readyto-eat_foods_on_the_market.pdf

Ismail, N. \& Kaur, B. (2013). Consumer preference for jackfruit varieties in Malaysia. Journal of Agribusiness Marketing, 6: 37-51. 
http://www.fama.gov.my/documents/20143/0/v6+3.pdf /1727b12d-f077-f5e4-21d1-73aa6166470d

James, S.J. \& James, C. (2014). Chilling and freezing of foods. In S. Clark, S. Jung \& B. Lamsal, (Eds.). Food Processing. NJ: John Wiley \& Sons, Ltd.

Latifah, M.N., Shukor, A.R.A., Aziz, I.A., Habsah, M., Talib, Y., Rahman, K.M. \& Jabir, H. (2000). Quality of minimally processed jackfruit stored at different temperatures. Journal of Tropical Agriculture and Food Science, 28(1): 8794.

Lubomír, K. \& Viera, K. (2015). Determination of mechanical properties of apple cultivar golden delicious. Journal on Processing and Energy in Agriculture, 19(1): 17-20.

Majidi, H., Minaei, S., Almasi, M. \& Mostofi, Y. (2011). Total soluble solids, titratable acidity and ripening index of tomato in various storage conditions. Australian Journal of Basic and Applied Sciences, 5(12): 1723-1726.

https://pdfs.semanticscholar.org/98ed/b4dc206ad08f77d ca16d04035e72b33ebbe0.pdf

Mirdehghan, S.H., Rahemi, M., Martínez-Romero, D., Guillén, F., Valverde, J.M., Zapata, P.J., Serrano, M. \& Valero, D. (2007). Reduction of pomegranate chilling injury during storage after heat treatment: Role of polyamines. Postharvest Biology and Technology, 44(1): 19-25. https://doi.org/10.1016/j.postharvbio.2006.11.001

Nair, H. \& Tung, H.F. (1988). Postharvest physiology and storage of pisang mas. In: Proceedings of the UKM Simposium Biology Kebangsaan Ketiga, Kuala Lumpur: pp: 22-24.

Nambi, V.E., Thangavel, K., Manickavasagan, A. \& Shahir, S. (2017). Comprehensive ripeness-index for prediction of ripening level in mangoes by multivariate modelling of ripening behavior. International Agrophysics, 31: 35-44.

http://archive.sciendo.com/INTAG/intag.2017.31.issue1/intag-2016-0025/intag-2016-0025.pdf

Padmanabhan, S. \& Heinz, H.J. (1985). Methods in Legumerhizobium Technology. Netherlands: Springer-Verlag.

Ranganna, S. (1986). Handbook of Analysis of Fruit and Vegetable Products (2nd Ed.) (1986). McGraw-Hill Education.

Saxena, A., Bawa, A.S. \& Raju, P.S. (2008). Use of modified atmosphere packaging to extend shelf-life of minimally processed jackfruit (artocarpus heterophyllus l.) bulbs. Journal of Food Engineering, 87(4): 455-466. https://doi.org/10.1016/j.jfoodeng.2007.12.020

Saxena, A., Bawa, A.S. \& Raju, P.S. (2012). Effect of minimal processing on quality of jackfruit (artocarpus heterophyllus l.) bulbs using response surface methodology. Food and Bioprocess Technology, 5(1): 348-358. https://doi.org/10.1007/s11947-009-0276-x

Swami, S.B., Thakor, N.J., Haldankar, P.M. \& Kalse, S.B. (2012). Jackfruit and its many functional components as related to human health: A review. Comprehensive Reviews in Food Science and Food Safety, 11(6): 565-576. https://doi.org/10.1111/j.1541-4337.2012.00210.x

Sweetman, C., Sadras, V.O., Hancock, R.D., Soole, K.L. \& Ford, C.M. (2014). Metabolic effects of elevated temperature on organic acid degradation in ripening vitis vinifera fruit. Journal of Experimental Botany, 65(20): 5975-5988. https://doi.org/10.1093/jxb/eru343

Thompson, A.K. (2014). Fruit and vegetables: Harvesting, Handling and Storage (Vol. 2). Wiley.

Wu, D. \& Sun, D.W. (2013). Colour measurements by computer vision for food quality control - a review. Trends in Food Science \& Technology, 29(1): 5-20. https://doi.org/10.1016/j.tifs.2012.08.004 